\title{
Políticas das artes, artes das políticas
}

A urgência e a determinação de explorar alguns dos liames diversos pelos quais as artes se manifestam politicamente, isto é, voltando às costas para os saberes e fazeres instituídos, que elas desafiam e ameaçam, e com isso afirmando uma negatividade radical, é confirmada, nesta edição da outra travessia, pela quantidade e qualidade dos artigos que recebemos, parte dos quais aqui publicados. É também emblemática a pluralidade das modalidades artísticas contempladas nos 19 ensaios selecionados, que vão do muralismo às artes plásticas, da poesia ao romance, passam pelo teatro e se projetam na direção do cinema e da música. A esse plural das artes corresponde uma multiplicidade das disposições teóricas, críticas e analíticas, sempre mobilizadas, de todo modo, em função de seu imanente potencial político.

Assim, Maria Aparecida Fontes, em “'Arte de passagem', lugares de sentido, política e poder”, contrapõe os murais realizados por Mario Sironi no âmbito do fascismo italiano àqueles criados por Cândido Portinari, que com seu trabalho se mostra avesso a diretrizes políticas e ideológicas características do Estado Novo. Artur de Vargas Giorgi, com "León Ferrari: fazer comum", concentra-se notadamente na impactante produção de Ferrari durante o seu exílio paulistano (entre 1976 e 1984), percebendo nela que as fronteiras e as capturas nacionais e nacionalistas não obliteram a procura obstinada do artista por acessos a orlas de sentidos, gesto poético por excelência. "Experiencia y memoria en Los anillos de Saturno de W.G. Sebald: la ética/política del arte narrativo sebaldiano", de Belisario Zalazar, discute a ficção sebaldiana à luz das teses de Sobre o conceito da História, de Walter Benjamin, com especial atenção a questões relacionadas à memória. Jair Tadeu da Fonseca propõe uma articulação entre ficções literárias e cinematográficas apoiando-se em Glauber Rocha e Jorge Luis Borges. Com isso, em "Ficções do pensamento latino-americano: Borges, Glauber e outras cabeças cortadas", mostra a possibilidade do estabelecimento 
de um fértil diálogo inter-artístico que atravessa as restrições das fronteiras nacionais. Manoel Ricardo de Lima, por sua vez, acrescenta a esse atravessamento de limites espaciais a remontagem anacrônica. Ao aproximar Herberto Hélder de Pier Paolo Pasolini a partir das imagens dos punti luminosi, em "Herberto Helder, Pasolini e um lugar ainda mudo", argumenta que a política da arte, na medida em que afirma a existência do impossível, substitui o impasse da formalização por uma informe, ou nada formal, formalização do impasse.

Polêmicas literárias e políticas na França de Luís Felipe figuram como pano de fundo do ensaio de Fernanda Almeida Lima, que em "Revolta jeune-France, bousingotismo e licantropia: o republicanismo de Pétrus Borel (1809-1859)", enfoca o grupo do Pequeno Cenáculo. A autora discute, em especial, o republicanismo licantrópico de Pétrus Borel. Já a poesia e a crítica de Prudente de Moraes, neto, são abordadas por Leonardo D’Ávila de Oliveira, em "Prudente de Moraes, neto e a política cultural do Estado Novo". "A cachorra", poema assinado com o pseudônimo de Pedro Dantas, é no ensaio analisado com notável esmero, tendo em vista ressaltar a posição menos conformada do autor, sobretudo em seus textos poéticos, frente a políticas culturais do Estado Novo brasileiro. Ainda no terreno do lirismo, as mais recentes coletâneas da poesia de Martín Rodríguez são exploradas por Franca Maccioni, que em "Minar el hilo dorado de la prosa del Estado" as qualifica como máquinas, ou melhor, como "livros de guerra". A autora encontra nessa poesia uma resoluta atitude reativa contra o pragmatismo do senso comum econômico, complementado pelos viscerais mecanismos de controle e vigilância, isso através da proposição de outra articulação da violência, fortemente irônica, se não sacástica. Alexander Belivuk Moraes, em "Mario Levrero e o desenho: por uma leitura por vir", propõe um paradigma da negatividade com o qual procura levar até o extremo suas análises da arte e da escritura híbidas de Levrero, o que lhe permite aproximá-las do "regime estético das artes", tal como postulado por Jacques Rancière. Também Danielle Grace de Almeida se vale de premissas formuladas por Jacques Rancière para refletir sobre as Políticas da escrita de Francis Ponge, isto é, sobre a atuação da escrita poética como matriz para figurações de dizeres e pensares na modernidade tardia. Em "Francis Ponge e as razões da poesia", deste modo, ela identifica na poesia de Ponge a presença de modulações da escrita que proporcionam verdadeiras intervenções críticas, portanto políticas.

"(O comunismo responde com a) Politização da arte", de André Piazera Zacchi, propõe uma sorte de arqueologia acerca do conhecido diagnóstico de Walter Benjamin sobre a imprescindível necessidade de reação comum contra a estetização da 
política, característica dos fascismos de matizes os mais variados com os quais há muito convivemos. $\mathrm{O}$ autor recorre à conferência realizada por Benjamin, em 1934, "O autor como produtor”, para enfatizar que a crítica benjaminiana aos fascismos implica necessariamente uma destruição das relações tradicionais de produção, inclusive as artísticas. O ponto de chegada de André Zachi, o cinema, é o ponto de partida de Rodrigo Amboni, em "Memória, experiência e montagem", que a partir de filmes e escritos de Andrei Tarkovski propõe a necessidade de uma "montagem poética", para cuja compreensão recorre aos conceitos de narração, experiência e memória tal como discutidos em muitos dos escritos que nos legou Walter Benjamin. A imagem da polêmica, da polemiké tomada na sua acepção de combate, reaparece na formulação sintética com a qual Diego Moreira intitula seu ensaio: "A poesia é uma trincheira de guerra". Conforme o autor depreende do exame de ensaios de Paulo Leminski e de manifestos assinados por Roberto Piva, a poesia contempoânea deve procurar resistir à disciplinarização e mercantilização modernas, conclusão que sintomaticamente converge na direção daquela a que chega Franca Maccioni.

Em "No tabuleiro do xadrez: Beckett e Duchamp", Juan Manuel Terenzi toma o jogo de xadrez como chave analítica não apenas para pensar relações entre literatura e filosofia, mas também para a proposição de uma leitura de Fim de partida, de Beckett, peça em que o xadrez atuaria ao modo de uma alegoria. Esse âmbito alegórico do xadrez contrasta vivamente com o acento factual das escritas, imagens e imaginações testemunhais, tais como discutidas por Angela Guida e Raysa Luana da Silva Oliveira, em "Políticas da literatura de testemunho", ensaio no qual, citando Márcio Seligmann-Silva, as autoras ressaltam os vazios que assombram o testemunhos, dado seu caráter menos simbólico que indicial. E é justamente o testemunho de Georg Lucáks sobre a importância de sua leitura de Tonio Krüger, de Thomas Mann, e de Quando despertarmos dentre os mortos, de Henrik Ibsen, para a sua produção crítica inicial que motiva as reflexões de Sandro de Mello Justo, em "Estética e leitmotiv político: analisando o jovem Lukács a partir de Thomas Mann e Henrik Ibsen". Dilemas resultantes das tensões entre o idealismo artístico e a crueza da vida ordinária característica da economia e da sociabilidade burguesas são ali ressaltadas visando à discussão do anti-capitalismo romântico do jovem Lucáks.

José Ricardo da Costa, em "Erico Verissimo e as vozes da história em O senhor embaixador", relaciona algumas situações romanescas criadas por Erico Verissimo com reflexões propostas por estudiosos de relações internacionais. Em "Vida e comunidade em Clube da Luta e A praia”, Joacy Ghizzi Neto parte das narrativas de Chuck Palahniuk e Alex Garland para discorrer 
sobre relações entre indivíduos e comunidades de que fazem ou pretendem fazer parte, no quadro de um presente distópico. Finalmente, Marcos Daniel de Melo Ferreira, em "Atitude Anno Domini: resistência musical no álbum Chaos A.D. da banda Sepultura", propõe uma leitura das poesias cantadas pelo grupo heavy-metal tomando-as como reação a políticas higienistas e de controle dos corpos e das narrativas dos seres quaisquer a que somos reduzidos.

Agradecemos a colaboração dos membros do Conselho Consultivo da outra travessia e a participação de todos e todas os $\backslash$ as colegas que submeteram originais à presente edição da revista.

Os editores 